\title{
HYBRID MODEL FOR INNOVATION PROCESS MANAGEMENT
}

\author{
Dominika JAGODA-SOBALAK ${ }^{1 *}$, Agnieszka CZERWIŃSKA-LUBSZCZYK ${ }^{2}$ \\ ${ }^{1}$ Opole University of Technology, Faculty of Production Engineering and Logistics; \\ d.jagoda-sobalak@po.edu.pl, ORCID: 0000-0003-3085-6603 \\ ${ }^{2}$ University of Bielsko-Biala, Faculty of Management and Transport; aczerwinska@ath.bielsko.pl, \\ ORCID: 0000-0001-8100-8802 \\ * Correspondence author
}

Purpose: The main goal of the article is to present the authors' model of designing and implementing innovation.

Design/methodology/approach: The designed model is based on extensive literature analysis. The presented model includes, among others: creative problem methods (innovation design), methods of innovation process management, project management methods (implementation of innovations). The proposed model was verified on the basis of a case study.

Findings: The article describes the authors' hybrid model for innovation process management, its assumptions and main components. The model can support management of innovation in enterprises, creates a set of guidelines and recommendations.

Practical implications: The developed model aims to support enterprises in the design and implementation of innovation. A practical example makes it easier to understand the authors' ideas and their subsequent application.

Originality/value: The article describes hybrid model for innovation process management. The model is relevant to management theory, such as practical value for enterprises. The model supports the course of the innovation process.

Keywords: innovation process, project management, creative problem solving.

Category of the paper: Research paper.

\section{Introduction}

Innovations are a driver of technical progress and modern technologies, as well as the main stimuli of the competitiveness of enterprises. Innovative business models, innovative management technologies, and development of new markets, products and services continue to change the current economic reality. The ability to create innovations becomes a key factor supporting the development potential of an enterprise (Okoń-Hordyńka, 2010; Tidd, Bodley, 2002). Similarities between ideas underlying the management of innovations and projects 
should be noted. Management of an innovation process is also a one-time action, burdened with a high risk, and requiring the allocation of resources (including human, physical and time resources). Therefore, the use of tools and methods of these disciplines (fields) for a successful and effective implementation of process, product, organization, or marketing innovations appears appropriate. The innovation process requires a wealth of creativeness and the ability to think outside the box. Furthermore, inventive methods may also prove useful, as they actually encourage a creative way of thinking.

Today, the search for possibilities to support the process of designing and implementing innovations is not only justified, but necessary. The proposal for combining methods and tools from areas of innovation management and project management, supplemented with methods stimulating creativeness (of an inventive nature) has, therefore, a chance to form a complete and coplanar collection of guidelines for the effective implementation of innovations. Furthermore, this will contribute to the development of a creative organization which is able to follow a project approach to the implementation of innovations, by eliminating certain barriers that limit the innovativeness of enterprises.

In consequence, the main purpose of this article was to design a hybrid model for designing and implementing innovations based on creative problem solving, innovation management, and project management methods.

The proposed solution is to support enterprises in the innovation process and contribute to the growth of innovativeness in Poland. Delivering a set of methods (inventive, and those used in innovation and project management), together with guidelines for their use, will have an advantageous effect on the successfulness and effectiveness of designing and implementing innovations.

Studies required for designing and verifying the hybrid model for innovations were conducted in four steps:

- literature review,

- collection of empirical data in the form of a multiple case study,

- development of a hybrid model for innovation process management,

- verification of the model for innovation process management.

\section{Trends and concepts in the creation of innovations}

The numerous concepts aiming at supporting innovations and innovativeness are dissimilar depending on the nature of innovations, sources or the scope of implemented changes. An example of such classification is demand- and supply-driven innovations. In the first case, we are talking about a situation in which innovativeness is driven by market needs, and in particular, by the needs of consumers, while in the second case the situation is reversed 
- innovations are launched into the market by a company (with R\&D activities being their source), and then they are verified by the market. Current concepts concerning demand-driven innovations include mass customization, which means offering customized products or services to customers in the mass market, while maintaining low prices (Gilmore, and Pine, 1997; Zhang et al., 2018).

According to Kleemann and Voss, mass customization is "an isolated activity of a single customer focused on one product, and not a joint activity undertaken by many customers, aiming at modification of a certain type of products" (2008, pp. 5-26).

The mass customization concept is consistent with the main assumptions underlying UDI (User-Driven Innovation). The UDI's foundation is that customers are increasingly less interested in the available commercial range, and increasingly often they want to participate in the process of creating and developing products which they want to purchase later.

UDI is based on a better understanding and discovering visible and hidden needs and expectations of consumers by using information provided by those consumers, and, very frequently, through the use of their ideas and ready-made solutions. Additionally, it provides for the regular involvement of its users in the process of enterprise development (Nordic Council of Ministers, 2018).

A demand-driven concept which underlies UDI for innovation creation has many advantages. This approach results mainly in a better matching of production or service provision to the expectations of a final buyer; furthermore, the costs associated with the development of innovations or marketing are reduced (Baldassarre, 2017).

A Crowdsourcing concept, which means the sourcing of knowledge, ideas and inspirations from the crowd, i.e. from ordinary people, should also be mentioned. Usually, in crowdsourcing a task previously realized by company employees is separated and allocated to be executed by a specific community, typically, in the form of cooperation (but it can also be executed by individuals). This way, a likelihood that a solution obtained from the community will be better than the one developed by company employees increases (Howe, 2006).

The concept of open innovation holds a particularly important place amongst concepts of innovation development. The main assumption of this concept is that not only internal, but also external organization resources, coming from the enterprise environment (including its competitors) should be used in the creation of innovations.

The implementation of the Open innovation concept may concern two dimensions of company operations. First, this may be an outsider-in open innovation, based on resources coming to the company and enabling the use of external cooperation to, for instance, extend the company product range. We can also distinguish the inside-out open innovation, which is based on transferring some of the resources or projects outside the company (Baran, et al., 2012). 
The Design Thinking concept, which uses creative problem-solving methods, is also worth noting. This concept is characterized by an approach to the innovation process that is organized to some extent. Usually, it consists of the following stages: empathy, problem defining, generating ideas, prototyping, and testing.

All listed concepts focus on innovation design by marginalizing their implementation stage (Wolak, and Żmijewska, 2014; Rudawska, 2017). The article proposes a proprietary approach to the innovation process, which takes into account both the design stage and the innovation implementation, as well as factors determining success of these stages.

\section{Project management and the innovation process}

Designing and implementing innovations is an exceptionally complex process. It requires soft competences (such as creativeness and communication skills), technical skills (e.g. risk assessment, and technical and technological design), and economic justifications.

Some similarities between the management of innovations and projects should be noted. Due to widely understood changes accompanying the innovation process occurring at many planes of the organization (Karbownik, 2005), the use of the agile project management (APM) appears to be particularly desirable, as it perfectly reflects the essence of changes in projects (Kopczyński, 2014; Sońta-Drączkowska, 2018).

The use of agile methodology in innovative projects is supported by their common features:

- agile methodologies are dedicated to projects with a defined project objective, but without defined methods for its implementation. The method of working is less formalized, and space for creativeness, indispensable to the creation of innovative solutions, is ensured;

- in agile methodologies, requirement modification is possible. During the design process of innovations, any changes occurring in micro- and macroenvironment of an enterprise are continuously considered;

- in agile methodologies and in innovative projects (especially in demand-driven innovations), a particularly important role is assigned to continued contact with the customer, who becomes an integral part of the design team;

- both in the innovation process and in projects implemented using the methodology, changes in budgets are acceptable, but must be justified economically and accepted by the customer;

- a team plays a particularly important role in the use of an agile approach to projects, and to designing and implementing innovations. Such a team will be characterized by significant autonomy, the interdisciplinary experience of its members and their significant involvement, as well as by efficient communication. 
It should also be noted that innovative activities are cost-consuming and risky, and this is a consequence of the very nature of the innovative process (uniqueness, long freeze period, unevenness). The expenditures increase with an innovative project becoming more specific, while the more breakthrough and promising the innovation, the higher the associated risk (Janasz, 2015). Due to a high degree of uncertainty and specific determinants of innovative projects, they are more frequently unsuccessful (Salerno et al., 2015). The use of project risk management tools in the implementation of innovations also seems to be justified.

On the basis of the literature review, the risk associated with projects, including innovative ones, can be classified according to a source of its origin (Ericson, and Kastensson, 2011; Miorando et al., 2014; Spałek, 2016):

- internal risk, within which there are the following groups of risks associated with:

- project management methodology adopted by the enterprise,

- in-house strategy for the implementation of innovations,

- human resources,

- organizational culture,

- knowledge management,

- external risk associated with project stakeholders:

- competitors,

- cooperating partners,

- government - legal changes.

Risk identification and its assessment in the project is crucial for the success of the initiative (Pudło, 2012; Trzepizur, 2016). Uncertainty and dynamically changing conditions of innovative undertakings require the use of adequate approaches to the management of projects of this type.

Considering their adaptiveness, creativeness, fast actions focused on customer needs, as well as detailed analysis, agile methodologies can also be used in innovative projects. They can contribute to the successful and effective design and implementation of innovations. They will also allow to organize the innovation process, supporting it at its individual stages. The design approach to innovation management will support the advantageous allocation of all resources, flexible reaction to changing conditions in which enterprises have to operate, as well as high mobility and entrepreneurship in making risky decisions.

\section{Creative problem solving and the innovation process}

According to Wertheimer (Proctor, 2002), creative thinking means destroying and changing the structure of our knowledge on a given phenomenon in order to gain a new insight into its nature. Therefore, the understanding of how reality is perceived may significantly influence our 
ability for creative thinking. We talk about creativeness when we can organize our own thoughts in a way which leads directly to another understanding of a situation.

Creative problem solving is the most effective in situations where traditional methods have already been exhausted or when the solved problem is unique and unconventional (as in designing or implementing innovations).

The process of creative problem solving with inventive methods can be divided into the following stages (Rossman, 1931):

- noticing a need or inconveniences of previous solutions,

- analysis of needs and difficulties,

- evaluation of the current technical know-how in a given field,

- determining all possible variants of the solution,

- critical analysis of collected variants of the solution,

- formulation of an original concept for the new solution,

- experimental verification of a concept underlying the new solution and its possible elaboration.

A Soviet psychologist P.M. Jakobson proposes a more complex structure of the process underlying the creation of new technical solutions, covering seven stages (Jakobson, 1934):

- state of mental readiness (creative anxiety),

- noticing a need,

- formulating a task,

- searching for possible solutions,

- detailed specification of the nature of a selected solution,

- development of the concept underlying the solution,

- development of documentation and an analysis of the solution.

Taking into account the nature of inventive methods, one can distinguish methods based on: free associations (e.g. analogy, brainstorming, 66 discussion, Gordon, "crushing", incompetence, "new look", situational, teratological, using mistakes); methods based on forced associations (e.g. Delphi, "good examples", discovery matrix, analogical transfer, concept transfer, general statements, "new arrangement"), methods of an analytical nature ("voluntary limitations", morphological, graphic presentation, "details").

There are many methods available for creative problem solving and the generation of ideas (Jagoda-Sobalak, and Łapuńska, 2017). The selection of a method to be used depends on many factors. The creative potential of team members, the available time, the nature of the problem, or the stage of problem solving all have to be taken into account. CERMA (CERAMA is an acronym of the French name of the renowned Centre of Studies and Research on Applied Methodologies - Centre d'Etudes et Recherches en Méthodologie Appliquée) grouped the methods matching them to one of four stages: problem defining and recognition, information 
collection and problem modelling, problem analysis and evaluation, and finding solutions (Nęcka, 1994).

Inventive methods are some of the ways in which employees are motivated to search for innovative solutions, as they support creativeness and integration. They contribute to the development of a creative climate and creative organization.

\section{Hybrid model for innovation design and implementation}

The importance of innovations, as well as difficulties associated with their design and implementation, are the subject of many research and scientific works. There is no single correct and universal way to develop the innovative potential of enterprises. An attempt was made to create a hybrid model for designing and implementing innovations based on inventive (stimulating creativeness), innovation management, and project management methods (Figure1). The model was based on the literature review and multiple case studies conducted in Polish enterprises.

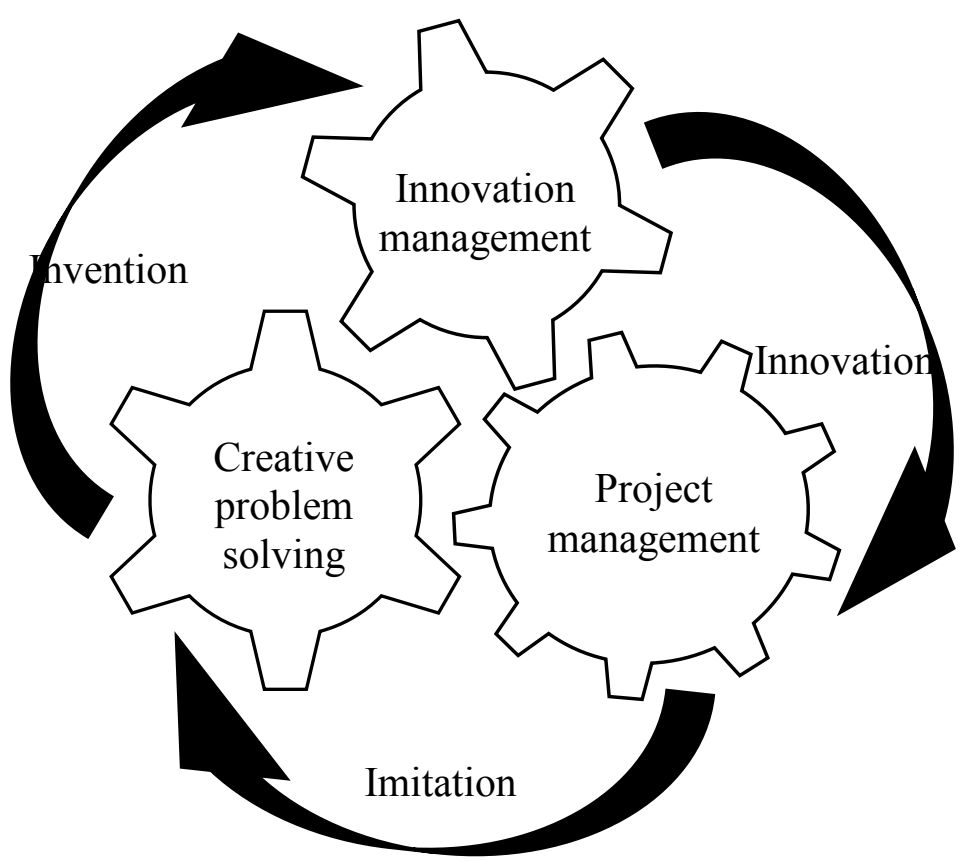

Figure 1. Innovation process model.

The collection of empirical data in the form of a multiple case study covered three stages:

- designing an innovative product using methods of creative problem solving,

- evaluation of innovative solutions using innovation management methods,

- implementation of an innovative solution using project management methods. 
The first stage of empirical research concerned the implementation of methods for creative problem solving into a process aimed at the stimulation of creativeness and presentation of new ideas - innovative solutions. The selection of the method had to be adapted to the creativeness level of organization employees, the time it could dedicate to searching for a solution, and the stage of the problem solving (Nęcka, 1994; Martyniak, 1997).

Creativeness tests and partly structured interviews were used to examine the creativeness of individual employees and the organization, as well as to determine the barriers limiting that creativeness. Furthermore, a participating observation was used during creative sessions in the process of generating ideas. During these sessions, enterprise employees were acquainted with inventive methods. The methods acquired were then used to generate innovative solutions.

The next stage in empirical research was the evaluation of designed solutions (a set of methods for innovation management). The methods used included Quicklook ${ }^{\mathrm{TM}}$ and In-Depth, developed by the Innovation, Creativity and Community (IC2) Institute at the University of Texas in Austin. In the Quicklook ${ }^{\mathrm{TM}}$ method, the research process consists of:

- identification of potential markets for technologies/innovations,

- identification of potential users and licensees,

- contacts with experts and enterprises,

- identifications of opportunities and factors being barriers to the development or implementation of technologies/innovations.

The In-Depth method represents a systematic and detailed analysis, which can be used to predict the consequences of the commercialization of innovations.

Therefore, market chances of the solutions proposed, their effectiveness, or possibilities for development were evaluated. From a set of creative (innovative) solutions, those to be implemented were selected.

The last stage of the tests involved the implementation of selected innovative solutions with the support of project management methods (project planning, project implementation and monitoring, with a focus on agile methodologies). The selection of methods was adapted to the maturity of the project team, the degree of project intricacy (complexity), and to the customer to whom that solution was dedicated. This stage required a significant involvement of the project manager and the use of their expert knowledge and experience. Therefore, in the future, there are plans to develop a tool supporting the selection of project management methods for a specific case (directions for further research).

The innovation process model is an attempt to adapt the organization to the changing environment and an increasingly demanding and competitive economy. The integration of methods for the management of creativeness, innovations and projects facilitates a creative approach to the innovation process. It should also be noted that the model of the innovation process includes feedback. Innovation implemented using the project approach develops 
a feeling of togetherness and stimulates to more effort aimed at the development of another innovative solution, which is then implemented using the project management methods.

Currently, longitudinal tests are in progress to confirm the influence of the developed innovation management model on the increase in the innovative potential of enterprises.

\section{Case study - innovation process in furniture industry}

One of the entities in which the case study was conducted was a furniture company located in the Opolskie Voivodeship. The enterprise produces high quality products for all rooms at home, specializing in widely understood wooden joinery. The company is well-established and recognized on the market, also by its loyal customers. Following the current trends in the furniture industry and the expectation of its customers, the company regularly implements innovative solutions.

\subsection{Designing innovative furniture using the method of creative problem solving}

Creative problem solving methods were used to design innovative solutions. Development of an innovative product (Figure 2) was compared to designing and tending of a garden (analogical transfer method).

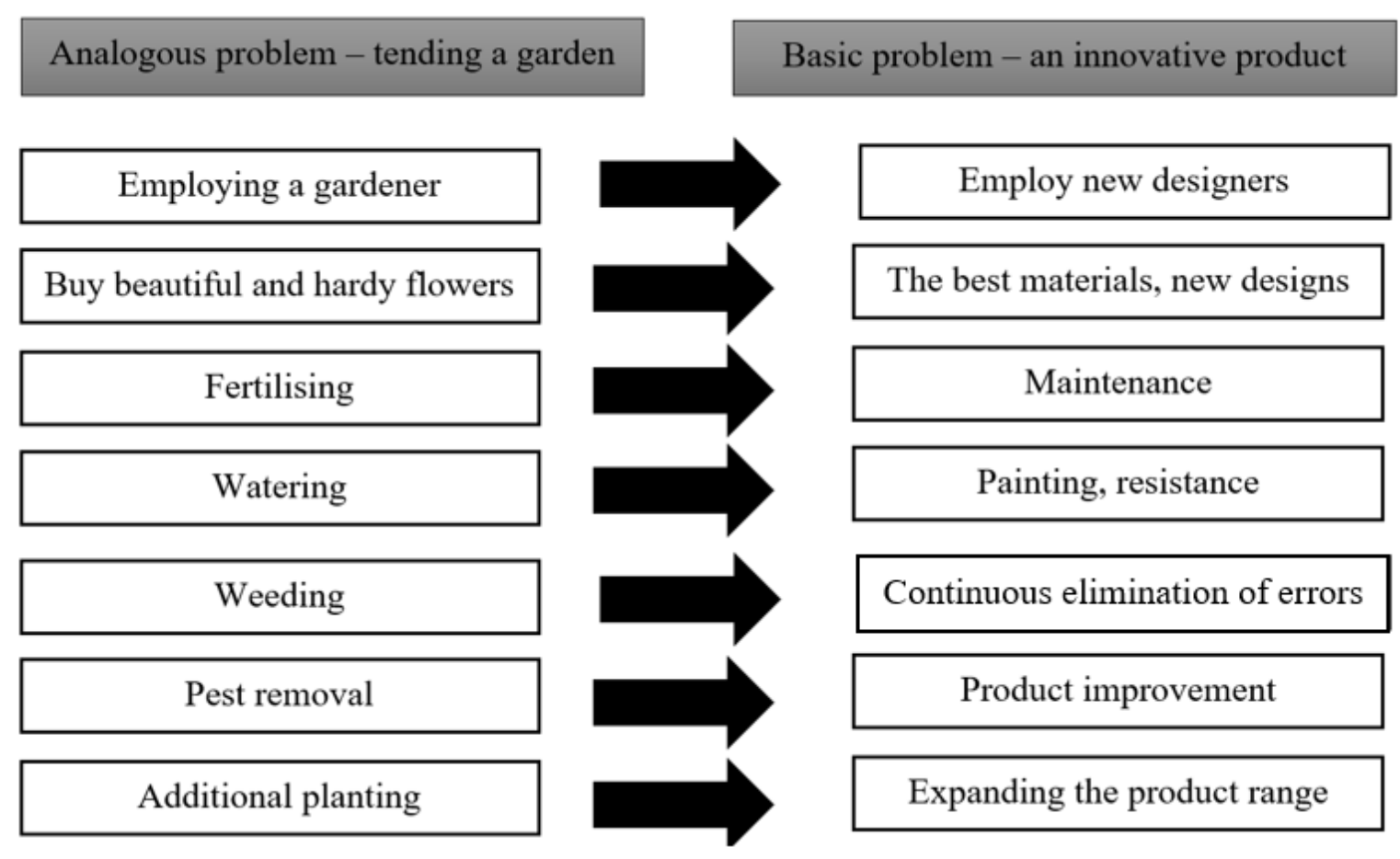

Figure 2. Analogical transfer method in product design. 
The selected method did not result in the development of an innovative product. However, it established features that this product should have. It was necessary to develop the concepts. The thought-map method was used. This method allowed not only to search for solution, but also to establish its features and directions for development. Seven solutions were generated - designs of innovative products. When production and organizational capacities were considered, four of them were deleted. Three of them passed to the solution evaluation stage: pro-environmental furniture made of recovered materials (from bales, pallets), furniture with printed Oriental patterns, and furniture with traditional decorations from the Opole region.

\subsection{Evaluation of innovative solutions using innovation management methods}

The ideas were evaluated using the Quicklook method. At the stage of market and user identification, the pro-environmental furniture was rejected. The company customers mostly value high-quality, luxurious products. Contacts with experts and other companies from sectors operating in the furniture market design from the Opole region. An expert evaluation was conducted. The designers (internal and external), employees, management, and customers positively evaluated the solutions proposed.

\subsection{Implementation of innovative solution using project management method}

From a set of creative (innovative) solutions, those to be implemented were selected. Previously, the company did not use project management methods, but cost estimation and production documentation were developed for the implemented products. Therefore, outsourcing or employing specialists was considered. As for many years the company has been cooperating with the Opole University of Technology, the university employees undertook to prepare and manage the implementation project. A project team was created, consisting of the company employees and scientists. The project was executed in the following stages (Highsmith, 2005):

- creation of the product vision - to create a vision for the customer and the project team, it also includes collecting information concerning customer requirements;

- designing - defining product requirements, specifying works as a list of functional elements, development of delivery elements with a time schedule and allocation of required resources to create individual functional elements, risk assessment, evaluation of project costs, and creation of the remaining financial or administrative information;

- exploring - this phase aims at delivering elements of product functionalities. It consists of three stages:

- delivery of functionality elements as a result of resource management, the use of appropriate techniques, and risk minimizing strategies;

- organizing a project community with its members cooperating with each other;

- managing connections between all project stakeholders; 
- adaptation - project execution in accordance with the plan; the performance is monitored, and when any deviations are found, corrections are implemented in the current plan. At this phase, the project is adapted, changes are implemented, and customer acceptance for product design modifications is obtained. The results of the adaptation phase are a starting point for the next loop of adaptation planning phases - exploring - adaptation. With each such loop, the product is improved;

- project closing - at this phase, knowledge is collected and used in subsequent iterations or transferred to another project team.

Internal and external risks associated with the planned project were analysed. Particular attention was paid to high customer expectations, and to a risk related to the organization of a system for innovation implementation (previously, the company did not manage implementations using the project methods). The increasing interest in signs and regional graphic designs, and the development of the furniture industry in the Opolskie Voivodeship were also taken into account.

The project prepared by university employees was accepted. Product implementation followed the adopted time schedule and cost estimations. The creation of an effective project team was an additional success. The implemented furniture line was launched in April 2019, and its sales have been rising steadily.

\section{Summary}

The design and implementation of innovations often influence the development and survival of an organization in a turbulent global economy. At the same time, it should be noted that innovative projects are characterized by their utilitarian nature, high risk and multiplanar integration (Wood, Logar, Riley, 2015; Pichlak, 2014). Therefore, conventional management methods appear to be insufficient. Taking the above into account, it was proposed to apply agile methods to the management of innovative projects. Furthermore, a complex management model was also proposed - model for designing and implementing innovations based on creative problem solving, innovation management, and project management methods.

Summing up, this article forms the basis for further extensive studies on the successfulness and effectiveness of the proposed model and its limitations. It is a premise for creating a system supporting an innovation process based on the proposed model. 


\section{References}

1. Baldassarre, B., Calabretta, G., Bocken, N.M.P., and Jaskiewicz, T. (2017). Bridging sustainable business model innovation and user-driven innovation: A process for sustainable value proposition design. Journal of Cleaner Production, Vol. 147 (March), 175-186.

2. Ericson, Å., and Kastensson, A. (2011). Exploit and Explore: Two Ways of Categorizing Innovation Projects. Proceedings of the 18th International Conference on Engineering Design (ICED 11), Denmark, Available online https://www.designsociety.org/downloadpublication/30516/exploit+and+explore\%3a+two+ways + of + categorizing+innovation + proj ects, 2.01.2019.

3. Gilmore, J.H., Pine II, B.J. (1997). The Four Faces of Customization. Harvard Business Review, 91-101.

4. Highsmith, J. (2005). Agile Project Management - Jak tworzyć innowacyjne produkty. Warszawa: Mikom.

5. Howe, J. (2006). The Rise of Crowdsourcing. Available online http://www.wired.com/ wired/archive/14.06/crowds.html, 5.01.2019.

6. Instytut IC2. Available online www.ic2.utexas.edu, 01.03.2019.

7. Jagoda-Sobalak, D., and Łapuńka I. (2017). Tool to support the design and implementation of innovative solutions. Proceeding CBU International Conference: Innovations in Science and Education, Praha, 128-1134.

8. Janasz, K. (2015). Zarządzanie ryzykiem innowacyjnym w organizacji. Studia i prace wydziału nauk ekonomicznych i zarządzania, nr 39, t. 1, 45-55.

9. Karbownik, A. (2005). Problemy w zarządzaniu projektami w przedsiębiorstwie. Zeszyty Naukowe, s. Organizacja i Zarzadzanie, z. 26. Gliwice: Wydawnictwo Politechniki Śląskiej, 118-137.

10. Kleemann, F., and Voss, G.G. (2008). Un(der)paid Innovators: The Commercial Utilization of Consumer Work through Crowdsourcing. Science, Technology \& Innovation Studies, Vol. 4(1), 5-26.

11. Kopczyński, T. (2014). Zwinne zarządzanie projektami jako elastyczne narzędzie strategii konkurowania poprzez innowację. Studia Oeconomica Posnaniensia, Vol. 2(11), 74-86.

12. Martyniak, Z. (1997). Wstęp do inwentyki. Kraków: Wydawnictwo Akademii Ekonomicznej.

13. Nęcka, E. (1994). Trop - twórcze rozwiąywanie problemów. Kraków: Oficyna Wydawnicza Impuls.

14. Nordic Council of Ministers, Understanding User-Driven Innovation, NORDEN, Copenhagen (2018). 
15. Okon'-Hordyńska, E. (2010). Trends in the development of competences for the innovative behavior - based on a survey conducted in four Polish municipalities. Proceedings International Conference COPE, Honolulu, 1-22.

16. Pichlak, M. (2014). Innowacje w polskich przedsiębiorstwach. Ekonomika i Organizacja Przedsiębiorstwa, $n r$ 5, 77-90.

17. Pudło, P. (2012). Charakterystyka barier rozwoju działalności innowacyjnej w ujęciu kapitału intelektualnego - wyniki badań. Nierówności Społeczne a Wzrost Gospodarczy, z. $n r$ 25, 81-90.

18. Rudawska, J. (2017). Bariery działalności innowacyjnej w sektorze przedsiębiorstw. Studium przypadku. Przedsiębiorstwo we współczesnej gospodarce/Research on enterprise in modern economy, $n r$ 1, 73-83.

19. Salerno, M.S., de Vasconcelos Gomes, L.A., da Silva, D.O., Bagno, R.B., and Teixeira Uchoa Freitas, S.L. (2015). Innovation processes: Which process for which project? Technovation, Vol. 35, 59-70.

20. Sońta-Drączkowska, E. (2018). Zarzadzanie projektami we wdrażaniu innowacji. Warszawa: PWE.

21. Spałek, S. (2016). Projekty innowacyjne. Istota i uwarunkowania, Nauki o Zarzadzaniu Management Sciences, $n r$ 1(26). Wrocław: Wydawnictwo Uniwersytetu Ekonomicznego, 131-142.

22. Tidd, J., and Bodley, K. (2002). The effects of project novelty on the new product development process. R\&D Management, Vol. 32, No. 2, 127-138.

23. Trzepizur, P. (2016). Zarządzanie innowacjami w małych i średnich przedsiębiorstwach. Zeszyty Naukowe Politechniki Częstochowskiej - Zarządzanie, nr 24, 52-62.

24. Wolak, D., and Żmijewska, A. (2014). Kierunki działań poprawiające efektywność wdrażania innowacji w firmach produkcyjnych sektora małych i średnich przedsiębiorstw. Economics and Managment, $n r$ 2, 58-68.

25. Wood, A., Logar, C.M., and Riley, W.B. (2015). Initiating exporting: The role of managerial motivation in small to medium enterprises. Journal of Business Research, Vol. 68(11), 2358-2365.

26. Zhang, M., Guo, H., Huo, B., Zhao, X., and Huang, J. (2018). Linking supply chain quality integration with mass customization and product modularity. International Journal of Production Economics, Vol. 207 (January), 227-235. 